\title{
Enhanced ZAG production by subcutaneous adipose tissue is linked to weight loss in gastrointestinal cancer patients
}

\author{
T Mracek ${ }^{1,4}$, NA Stephens ${ }^{2,4}$, D Gao', Y Bao', JA Ross ${ }^{2}$, M Rydén ${ }^{3}$, P Arner ${ }^{3}$, P Trayhurn', KCH Fearon ${ }^{2}$ \\ and C Bing*,I
}

'Obesity Biology Research Unit, School of Clinical Sciences, University of Liverpool, Liverpool L69 3GA, UK; '²Department of Clinical and Surgical Sciences (Surgery), University of Edinburgh, Edinburgh, UK; ${ }^{3}$ Department of Medicine, Karolinska Institutet at Karolinska University Hospital, Stockholm, Sweden

BACKGROUND: Profound loss of adipose tissue is a hallmark of cancer cachexia. Zinc- $\alpha 2$-glycoprotein (ZAG), a recently identified adipokine, is suggested as a candidate in lipid catabolism.

METHODS: In the first study, eight weight-stable and 17 cachectic cancer patients (weight loss $\geqslant 5 \%$ in previous 6 months) were recruited. Zinc- $\alpha 2$-glycoprotein mRNA and protein expression were assessed in subcutaneous adipose tissue (SAT), subcutaneous adipose tissue morphology was examined and serum ZAG concentrations were quantified. In the second cohort, ZAG release by SAT was determined in 18 weight-stable and 15 cachectic cancer patients. The effect of ZAG on lipolysis was evaluated in vitro. RESULTS: Subcutaneous adipose tissue remodelling in cancer cachexia was evident through shrunken adipocytes with increased fibrosis. In cachectic cancer patients, ZAG mRNA was upregulated (2.7-fold, $P=0.028)$ while leptin mRNA decreased $(2.2$-fold, $P=0.018)$; serum ZAG levels were found to be unaffected. Zinc- $\alpha 2$-glycoprotein mRNA correlated positively with weight loss ( $r=0.5 \mathrm{l}$, $P=0.01)$ and serum glycerol levels $(r=0.57, P=0.003)$. Zinc- $\alpha 2$-glycoprotein release by SAT was also elevated in cachectic patients $(\mathrm{I} .5$-fold, $P=0.024)$ and correlated with weight loss $(r=0.50, P=0.003)$. Recombinant ZAG stimulated lipolysis in human adipocytes.

CONCLUSIONS: Zinc- $\alpha 2$-glycoprotein expression and secretion by adipose tissue is enhanced in cachectic cancer patients. Given its lipid-mobilising effect, ZAG may contribute to adipose atrophy associated with cancer cachexia in human beings.

British Journal of Cancer (20I I) I 04, 44I-447. doi:I0.1038/sj.bjc.6606083 www.bjcancer.com

Published online 18 January 201।

(c) 20II Cancer Research UK

Keywords: zinc- $\alpha 2$-glycoprotein; gastrointestinal cancer; cachexia; adipose tissue; lipolysis

Cachexia, a catabolic syndrome manifested by profound loss of adipose tissue and skeletal muscle, affects most cancer patients (Fearon et al, 2006). Progressive cachexia has a detrimental effect on antitumour treatment and is associated with reduced survival (Dewys et al, 1980). Muscle wasting has been the focus of intensive research, with the demonstration of reduced protein synthesis and increased proteolysis in rodent models of cachexia and in cachectic cancer patients (Tisdale, 2005; Argiles et al, 2006). Fat loss occurs more rapidly than the reduction of lean mass in cancer cachexia (Fouladiun et al, 2005), with the most rapid loss of adipose tissue within 3 months of death (Lieffers et al, 2009). Although extensive depletion of body fat has been considered as a hallmark of cancer cachexia, the underlying molecular basis is poorly understood. A better knowledge of the mechanisms involved in adipose atrophy is crucial for the development of effective treatments for the syndrome.

Several factors derived from tumours and/or host tissues are implicated in fat depletion during progressive cachexia (Tisdale, 2005). These factors include inflammatory cytokines such as tumour necrosis factor $\alpha(\mathrm{TNF} \alpha)$ and lipolytic factors such as

\footnotetext{
*Correspondence: Dr C Bing; E-mail: bing@liverpool.ac.uk

${ }^{4}$ These authors contributed equally to this work.

Received 18 October 2010; revised 10 December 2010; accepted 13

December 2010; published online 18 January 2011
}

zinc- $\alpha 2$-glycoprotein (ZAG). Zinc- $\alpha 2$-glycoprotein, a secreted soluble protein, was initially isolated from human plasma (Burgi and Schmid, 1961), and subsequently found in various tissues (Tada et al, 1991). Zinc- $\alpha 2$-glycoprotein is overexpressed by several types of malignant tumour, such as breast, prostate and lung cancers (Diez-Itza et al, 1993; Hale et al, 2001; Albertus et al, 2008), and it has been proposed as a cancer biomarker. The physiological functions of ZAG remain to be established, but the protein has been implicated in hindering cell proliferation (He et al, 2001; Schmitt et $\mathrm{al}, 2008$ ) and modulating melanin production (Hale, 2002).

The most studied property of ZAG is its involvement in lipid metabolism (Bing and Trayhurn, 2009). Zinc- $\alpha 2$-glycoprotein has been shown to be identical to a lipid-mobilising factor (LMF) purified from the urine of patients with cancer cachexia (Todorov et al, 1998). Treatment with purified ZAG can induce selective reduction in body fat in both genetically obese $(o b / o b)$ mice and outbred NMRI mice (Hirai et al, 1998; Bing et al, 2002). In vitro, ZAG stimulates lipolysis in isolated murine and human adipocytes, and this has been postulated to be mediated by the $\beta_{3}$-adrenoceptor in rodents (Hirai et al, 1998). There is also evidence that ZAG promotes lipid utilisation through the upregulation of uncoupling protein-1 in brown fat (Bing et al, 2002) and increasing overall fatty acid oxidation (Russell and Tisdale, 2010).

Adipose tissue plays important roles in energy homeostasis and metabolism through secreted adipokines (Trayhurn and 
442

Bing, 2006). The fat-lowering effect of ZAG and the secretory function of adipose tissue led to the hypothesis that ZAG could be produced by adipose tissue, thereby influencing adipocyte metabolism (Bing et al, 2004). Indeed, our previous work has shown that the $Z A G$ gene and protein is expressed in the major fat depots of mice and human beings (Bing et al, 2004). Subsequently, ZAG was shown to be secreted by differentiated human adipocytes (Bao et al, 2005) at levels comparable with adiponectin, one of the most abundant proteins in adipose tissue (Mracek et al, 2010a); ZAG, therefore, is a major adipokine. Recent evidence suggests that adipose tissue-derived ZAG is inversely linked to adiposity. Zinc- $\alpha 2$-glycoprotein gene and protein expression in adipose tissue is downregulated in obese ob/ob mice (Mracek et al, 2010b) and in obese human subjects (Selva et al, 2009). In contrast, ZAG mRNA and protein levels are substantially increased in adipose tissue of tumour-bearing mice with profound fat loss, suggesting a role for ZAG in adipose tissue catabolism (Bing et al, 2004).

Despite this knowledge, the clinical relevance of ZAG in human cancer cachexia is still not known. In this study, we investigated the potential role of adipokine ZAG in the pathogenesis of cancer cachexia in human beings. Zinc- $\alpha 2$-glycoprotein expression and secretion by adipose tissue (subcutaneous) was examined along with serum ZAG levels in cancer patients with cachexia as compared with weight-stable controls. We also analysed the relationship between adipokine ZAG (expression and release) and the extent of weight loss in cancer patients. Finally, the effect of recombinant ZAG protein on lipid mobilisation in human adipocytes was assessed.

\section{MATERIALS AND METHODS}

\section{Patients and sample collection}

Twenty-five cancer patients (upper gastrointestinal, $n=12$; pancreatic, $n=13$ ) were recruited at the Department of Clinical and Surgical Sciences, University of Edinburgh. Patients did not receive previous anticancer therapy and underwent potentially curative abdominal surgery. The weight and height of the subjects were measured, and body mass index (BMI) and total fat mass were calculated (Moses et al, 2001). Mid-arm muscle circumference (MAMC) was calculated from triceps skin-fold thickness (TSF) and total mid-arm circumference (MAC): MAMC = MAC $-[\pi \times \mathrm{TSF}]$. For each patient, pre-illness stable weight was self-reported and the percentage of weight loss was calculated. The patients were divided into cachectic $(n=17)$ and weight-stable $(n=8)$ groups. Cachexia was defined as unintentional weight loss $\geqslant 5 \%$ during the previous 6 months; weight-stable patients were defined as patients without apparent weight change during the previous 6 months.

Patients had fasted overnight before undergoing surgery. A venous blood sample was taken before the surgical procedure and centrifuged to obtain serum, which was subsequently stored at $-80^{\circ} \mathrm{C}$ for later analysis. An open biopsy of approximately $1-2 \mathrm{~g}$ of abdominal subcutaneous adipose tissue (SAT) was obtained at the start of the surgical procedure. Samples were rinsed in PBS and snap-frozen immediately in liquid nitrogen, and then stored at $-80^{\circ} \mathrm{C}$ until later analysis.

For the study of ZAG protein release by adipose tissue, another cohort of 34 patients with gastrointestinal cancer (oesophagus, $n=8$; pancreas, $n=12$; stomach, $n=4$; gall bladder, $n=2$; and colon, $n=5$ ) and liver metastasis with no clear primary tumour $(n=3)$ were recruited at the Karolinska University Hospital, Stockholm, Sweden. Among them, 15 patients experienced weight loss ( $\geqslant 5 \%$ during the previous 6 months) and 19 were weight stable. The patients were investigated after an overnight fast. Height and weight was determined and body composition assessed by whole-body electrical bioimpedance (Quad Scan 4000; Bodystat, Isle of Man, UK). Abdominal SAT ( $\sim 500 \mathrm{mg}$ ) was taken by needle biopsy and immediately processed for measurements of in vitro protein secretions, as described previously (Ryden et al, 2008).

Tumour stage was assessed according to the AJCC/UICC system (Sobin, 2002). Fully informed, written consent was obtained in all cases and the study protocol was approved by the appropriate Regional Human Ethics Committees.

\section{Histology}

Subcutaneous adipose tissue biopsies from cachexia and weightstable cancer patients were fixed in $10 \%$ neutral formalin for $24 \mathrm{~h}$, dehydrated in absolute ethanol, cleared in xylene and then embedded in paraffin. The paraffin was cut into $5-\mu \mathrm{m}$ sections that were stained with Harris haematoxylin, counterstained with eosin, and then evaluated and photographed under light microscopy. To detect the collagen-fibre content in SAT, sections were stained with Sirius Red (Bing et al, 2006).

\section{RNA extraction and real-time PCR}

Total RNA was extracted from tissues or cells using Trizol (Invitrogen, Carlsbad, CA, USA). First-strand cDNA was reverse transcribed from $0.5 \mu \mathrm{g}$ of total RNA using an iScript first-strand synthesis kit (BioRad, Hercules, CA, USA) in a final volume of $10 \mu \mathrm{l}$. Real-time PCR amplification was performed in a final volume of $12.5 \mu \mathrm{l}$, containing cDNA (equivalent to $10 \mathrm{ng}$ of RNA), primers, TaqMan probe FAM-TAMRA and a master mix made from qPCR core kit (Eurogentec, Seraing, Belgium) using a Stratagene $\mathrm{Mx} 3005 \mathrm{P}$ instrument. The sequence of primers and probe for human ZAG, leptin and $\beta$-actin were as described previously (Bing et al, 2004; Bao et al, 2005). Polymerase chain reaction cycling conditions were: $95^{\circ} \mathrm{C}$ for $10 \mathrm{~min}$, followed by 40 cycles $\left(95^{\circ} \mathrm{C}\right.$ for $15 \mathrm{~s}, 60^{\circ} \mathrm{C}$ for $\left.1 \mathrm{~min}\right)$. Samples were normalised to $\beta$-actin and the results expressed as fold changes of $C_{\mathrm{t}}$ value relative to controls using the $2^{-\Delta \Delta C_{\mathrm{t}}}$ formula.

\section{Measurement of SAT ZAG protein}

For quantification of ZAG protein levels, SAT samples were homogenised using glass/glass homogenisers in buffer consisting of $250 \mathrm{~mm}$ sucrose, $10 \mathrm{~mm}$ Tris- $\mathrm{HCl}(\mathrm{pH} 7.4), 1 \mathrm{~mm}$ EDTA and protease inhibitor cocktail (dilution 1:500; Sigma, Poole, Dorset, UK). Homogenates were spun down at $12000 \mathrm{~g}$ for $10 \mathrm{~min}$ at $4{ }^{\circ} \mathrm{C}$ and upper fat layer was discarded. Infranatant and sediment were rehomogenised by pipetting up and down before being used for assay. The total protein content of the homogenates was determined by the BCA protein assay reagent (Sigma). Zinc- $\alpha 2-$ glycoprotein protein content in tissue homogenates was measured with an enzyme-linked immunosorbent assay (ELISA) kit (BioVendor, Rosice, Czech Republic) according to the manufacturer's protocol. Zinc- $\alpha 2$-glycoprotein protein levels were normalised to total protein content.

\section{Measurement of SAT ZAG secretion}

Subcutaneous adipose tissue explants were incubated as described previously (Ryden et al, 2008). In brief, adipose tissue (about $300 \mathrm{mg}$ ) was incubated in $3 \mathrm{ml}$ of medium for $2 \mathrm{~h}$ at $37^{\circ} \mathrm{C}$. The incubation medium was then collected from each sample and centrifuged at 1000 r.p.m. for $10 \mathrm{~min}$ to remove cell debris and the supernatant was stored at $-80^{\circ} \mathrm{C}$ until analysis. The tissue was collected and subjected to lipid extraction. Zinc- $\alpha 2$-glycoprotein secretion by adipose tissue was determined as the protein concentration in the medium using an ELISA kit (BioVendor, Rosice, Czech Republic) and related to the lipid weight of the incubated tissue. 


\section{Serum analyses}

Serum ZAG levels were measured using an ELISA kit (BioVendor). Serum leptin levels were also evaluated by ELISA (R\&D Systems, Abingdon, UK). The concentrations of serum albumin and lipids were determined by standard methods employed by the clinical chemistry laboratories.

\section{Culture of adipocytes}

SGBS (Simpson-Golabi - Behmel syndrome) cells, kindly provided by Professor $M$ Wabitsch, were maintained and cultured as described previously (Bao et al, 2005). In brief, cells were cultured at $37^{\circ} \mathrm{C}$ in a humidified atmosphere of $5 \% \quad \mathrm{CO}_{2} / 95 \%$ air. SGBS preadipocytes were maintained in DMEM/Ham's F12 (1:1) medium (Invitrogen, Paisley, UK) containing $10 \%\left(\mathrm{vv}^{-1}\right)$ foetal calf serum (FCS; Sigma) and antibiotics (penicillin/streptomycin; Lonza, Twekesbury, UK). Preadipocytes were seeded onto 12-well plates and grown until confluence. At confluence, cells were induced to differentiate (day 0 ) by incubation for 5 days in FCS free medium containing $0.25 \mu \mathrm{M}$ dexamethasone, $500 \mu \mathrm{M}$ 3-isobutyl-1-methylxanthine, $10 \mathrm{~nm}$ insulin, $200 \mathrm{pm}$ triiodothyronine $\left(\mathrm{T}_{3}\right), 1 \mu \mathrm{M}$ cortisol (all from Sigma) and $2 \mu \mathrm{m}$ rosiglitazone (GlaxoSmithKline, Uxbridge, UK). Cells were then maintained in feeding medium (containing $10 \mathrm{nM}$ insulin, $1 \mu \mathrm{M}$ cortisol and $200 \mathrm{pM} \mathrm{T}_{3}$, all from Sigma) until full differentiation, verified by observing the accumulation of lipid droplets under the microscope.

For the study of the effect of ZAG on lipolysis, differentiated SGBS adipocytes (day 15) were treated with 5 or $20 \mu \mathrm{g} \mathrm{ml}^{-1}$ recombinant ZAG (BioVendor) for $18 \mathrm{~h}$. Isoproterenol $(10 \mu \mathrm{M})$ or IBMX $(100 \mu \mathrm{M})$ was similarly incubated with the cells as positive references. Cells without the addition of any agents were used as controls. At the end of incubation, the culture medium was collected and lipolysis was determined as glycerol release into the medium using a commercial kit (Sigma).

\section{Statistical analysis}

Differences between the two groups were analysed by Student's unpaired $t$-test for normal distributed data. Mann-Whitney test was used for data with a non-normal distribution and data were presented as median with 75 th percentile. Non-parametrical $\chi^{2}$ test was performed to compare difference of the tumour stage between the two groups. Associations between quantitative variables were assessed with Spearman's rank correlation test. Statistical analyses were performed using SPSS program, and statistical difference was considered as significant when two-tailed $P<0.05$.

\section{RESULTS}

\section{Characteristics of patients}

The clinical characteristics of patients (the UK cohort and the Swedish cohort) are presented in Table 1. There were no significant differences in gender or age between cachectic and weight-stable cancer patients. Cachectic patients had a lower BMI ( $P=0.0015$, UK cohort), fat mass $(P=0.01-0.016$, both cohorts $)$ and MAMC ( $P=0.0082$, measured only in the UK cohort), but greater weight loss $(P<0.0001$, both cohorts $)$ compared with weight-stable patients. With respect to tumour stage, no significant difference was found between the two groups (both cohorts).

There was no significant difference in the serum concentration of ZAG between cachectic and weight-stable cancer patients (55.3 \pm 10.9 vs $58.7 \pm 7.7, P=0.45$ ) (Table 1). Serum ZAG levels showed no correlation with BMI $(r=0.092, P=0.66)$ or weight loss $(r=-0.11, P=0.61)$. In contrast, serum leptin levels were lower (by $53 \%, P=0.035$ ) in cachectic patients compared with weightstable cancer patients (Table 1). Serum leptin also showed a positive correlation with $\mathrm{BMI}(r=0.61, P=0.0018)$ and an inverse correlation with weight loss $(r=-0.53, P=0.0098)$.

\section{Adipose tissue remodelling in patients with cancer cachexia}

Examination under light microscopy showed substantial morphological alterations of SAT in cachectic cancer patients compared with weight-stable cancer controls. The changes were characterised by the tissue containing shrunken adipocytes and this was paralleled by an increase in interstitial space (Figure 1A). To

Table I Anthropometric, biochemical and hormonal characteristics of cancer patients

\begin{tabular}{|c|c|c|c|c|c|c|}
\hline & \multicolumn{3}{|c|}{ UK cohort } & \multicolumn{3}{|c|}{ Swedish cohort } \\
\hline & Weight stable $(n=8)$ & Cachectic $(n=17)$ & $P$-value & Weight stable $(n=19)$ & Cachectic $(n=15)$ & $P$-value \\
\hline Males/females (n) & $7 / 1$ & $8 / 9$ & 0.088* & $14 / 5$ & $13 / 2$ & $0.35^{\#}$ \\
\hline Age (years) & $67 \pm 6$ & $64 \pm 10$ & 0.69 & $66 \pm 7$ & $64 \pm 11$ & 0.49 \\
\hline $\mathrm{BMI}\left(\mathrm{kg} \mathrm{m}^{-2}\right)$ & $28.0 \pm 3.4$ & $22.8 \pm 3.4$ & 0.0015 & $25.7 \pm 3.5$ & $23.3 \pm 4.2$ & 0.072 \\
\hline Total fat mass (kg) & $25.2 \pm 4.4$ & $18.1 \pm 6.4$ & 0.010 & & N/A & \\
\hline Body fat (\%) & $30.8 \pm 3.7$ & $27.1 \pm 4.8$ & 0.060 & $27.3 \pm 3.7$ & $21.7 \pm 8.4$ & 0.0016 \\
\hline MAMC $(\mathrm{cm})$ & $26.5 \pm 2.9$ & $23.2 \pm 2.4$ & 0.0082 & & N/A & \\
\hline Weight loss (\%) & $0.3(0.7)$ & | $1.8(16.8)$ & $<0.0001^{\dagger}$ & $1.2 \pm 2.7$ & $13.3 \pm 6.3$ & $<0.0001$ \\
\hline \multicolumn{7}{|l|}{ Tumour stage } \\
\hline l = & 3 & 3 & $0.26^{\#}$ & 2 & | & $0.28^{\#}$ \\
\hline 2 & 0 & 6 & & 0 & 0 & \\
\hline 3 & 2 & 3 & & 8 & | | & \\
\hline 4 & 2 & 3 & & 8 & 3 & \\
\hline Albumin $\left(\left.g\right|^{-1}\right)$ & $36.9 \pm 3.9$ & $32.7 \pm 5.4$ & 0.064 & $37.9 \pm 2.6$ & $34.0 \pm 3.7$ & 0.0017 \\
\hline Triglycerides (mmoll ${ }^{-1}$ ) & $1.28 \pm 0.74$ & $1.26 \pm 1.04$ & 0.96 & $1.20 \pm 0.35$ & $1.08 \pm 0.42$ & 0.37 \\
\hline Cholesterol $\left(\mathrm{mmoll}^{-1}\right)^{\prime}$ & $4.94 \pm 1.92$ & $4.01 \pm 1.30$ & 0.16 & $4.85 \pm 1.09$ & $4.47 \pm 1.16$ & 0.35 \\
\hline Glycerol $\left(\mu \mathrm{g} \mathrm{ml}^{-1}\right)$ & $0.44 \pm 0.25$ & $0.64 \pm 0.37$ & 0.19 & & N/A & \\
\hline \multicolumn{7}{|l|}{ Total fat mass $(\mathrm{kg})$} \\
\hline Serum ZAG $\left(\left.\mu \mathrm{g} \mathrm{m}\right|^{-1}\right)$ & $58.7 \pm 7.7$ & $55.3 \pm 10.9$ & 0.45 & & N/A & \\
\hline Serum leptin (ng ml-1) & $13.7 \pm 6.0$ & $6.6 \pm 7.3$ & 0.035 & & N/A & \\
\hline
\end{tabular}

Abbreviations: $\mathrm{BMI}=$ body mass index; $\mathrm{MAMC}=$ mid-arm muscle circumference; $\mathrm{N} / \mathrm{A}=$ not applicable; ZAG $=$ Zinc- $\alpha 2$-glycoprotein. Tumour stage was not available on one weight-stable patient from the Swedish cohort. Values are means \pm s.d. or median (75th percentile). They were compared by either an unpaired Student's $t$-test, $\chi^{2}$ test $\left({ }^{\#}\right)$, Mann-Whitney test $\left(^{\dagger}\right)$ or Fisher's exact test $(*)$. 

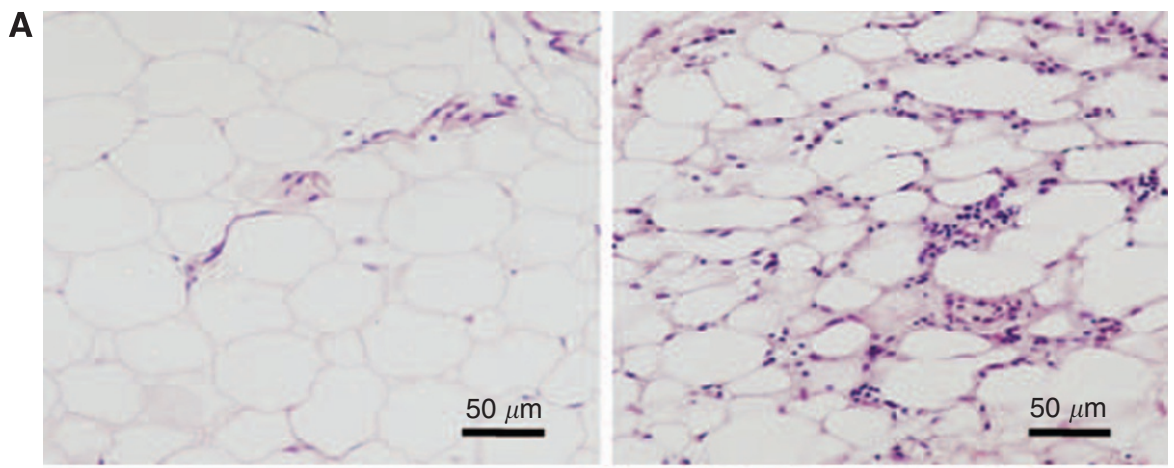

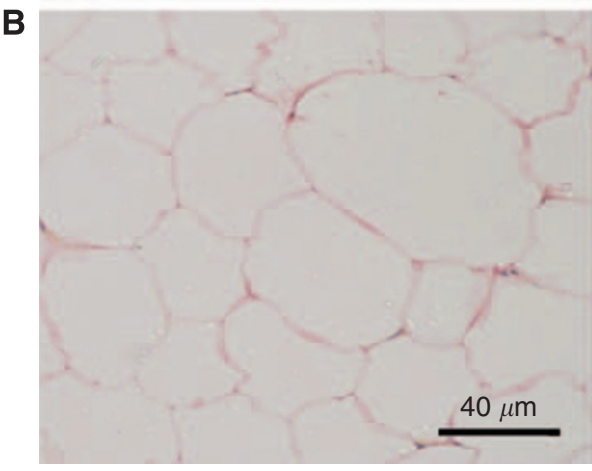

Weight stable

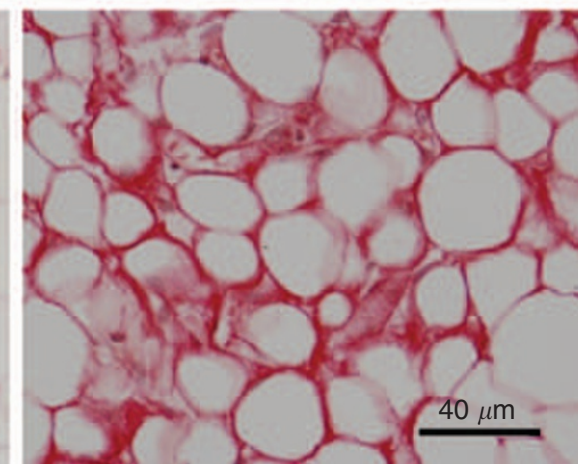

Cachectic

Figure I Morphological characteristics of adipose tissue in cachexia. Representative sections of subcutaneous adipose tissue from weight-stable and cachectic cancer patients stained with haematoxylin-eosin (A) or Sirius Red (B).

further examine the nature of the extracellular matrix, sections of SAT were stained with Sirius Red. There was a strong Sirius Red staining in the stroma of adipose tissue from cachectic patients, which indicates a substantial increase in collagen-fibre content in the tissue (Figure 1B).

\section{ZAG expression in SAT is upregulated in cachectic cancer patients}

Subcutaneous adipose tissue ZAG mRNA levels were significantly higher in cachectic cancer patients than in weight-stable cancer patients (2.7-fold, $P=0.028$ ) (Figure $2 \mathrm{~A}$ ). In contrast, mRNA levels of leptin, known as an indicator of adiposity and here used as a reference gene for ZAG, were significantly reduced in cachectic patients (2.2-fold, $P=0.018$ ) (Figure $2 \mathrm{~B})$. Further analysis of ZAG protein expression in SAT showed an increase in cachectic patients compared with weight-stable cancer patients, but this was not statistically significant (1.4-fold, $P=0.076)$ (Figure 2C). In addition, ZAG protein levels exhibited a positive correlation with ZAG mRNA levels in SAT ( $r=0.42, P=0.04)$ (Figure 2D).

\section{ZAG expression in SAT is associated with weight loss}

To further investigate whether adipokine ZAG has a potential role in the pathogenesis of cancer cachexia in human beings, the relationship between SAT ZAG mRNA levels and several aspects of nutritional status were analysed. As shown in Figure 3A, ZAG mRNA levels correlated negatively with BMI $(r=-0.50, P=0.01)$. In contrast, ZAG mRNA showed a positive correlation with weight loss $(r=0.51, P=0.01)$ (Figure 3B). Furthermore, analysis of the potential link between adipokine ZAG and lipolysis revealed that ZAG mRNA levels correlated positively with serum glycerol levels $(r=0.57, P=0.003)$ (Figure 3C). In addition, SAT ZAG protein levels also showed an inverse relationship with BMI $(r=-0.41$,
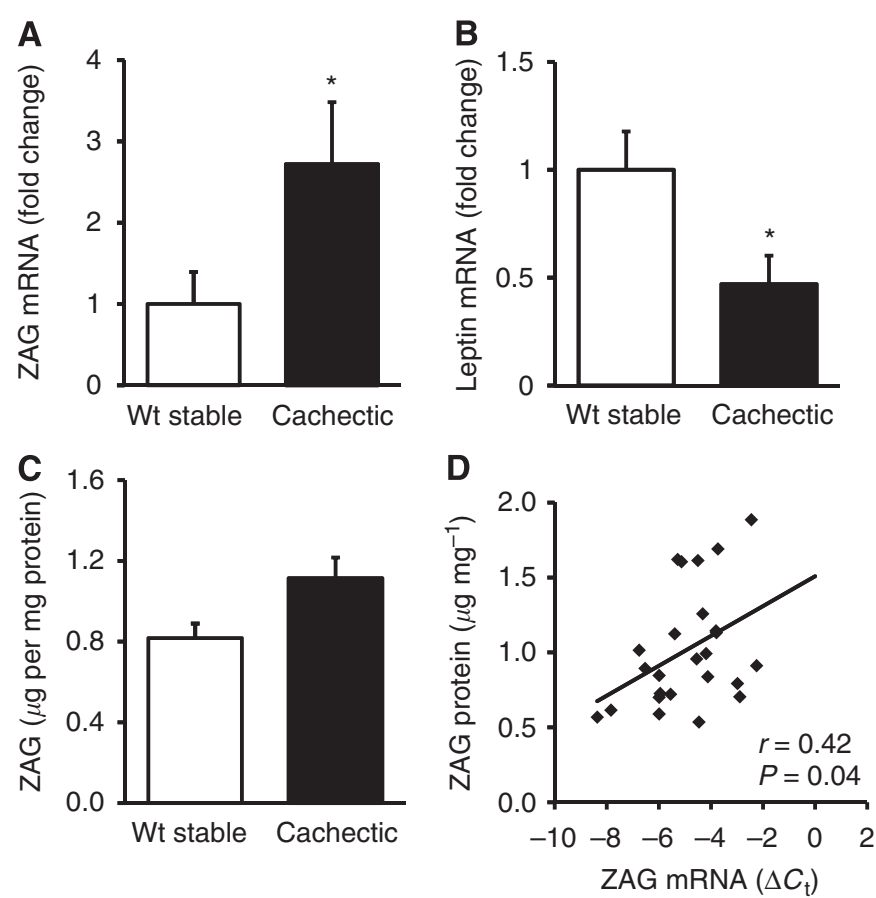

Figure 2 Zinc- $\alpha 2$-glycoprotein gene and protein expression in adipose tissue of cancer patients. mRNA levels of ZAG $(\mathbf{A})$ and leptin $(\mathbf{B})$ in subcutaneous adipose tissue of weight-stable $(n=8)$ and cachectic $(n=17)$ cancer patients by real-time PCR, expressed as means \pm s.e.m. Zinc- $\alpha 2$ glycoprotein protein levels in subcutaneous fat of weight-stable $(n=8)$ and cachectic $(n=17)$ cancer patients by ELISA, expressed as means \pm s.e.m. (C) Correlation between ZAG protein and mRNA levels (D) in adipose tissue; $n=25$. $* P<0.05$ compared with weight-stable patients. 

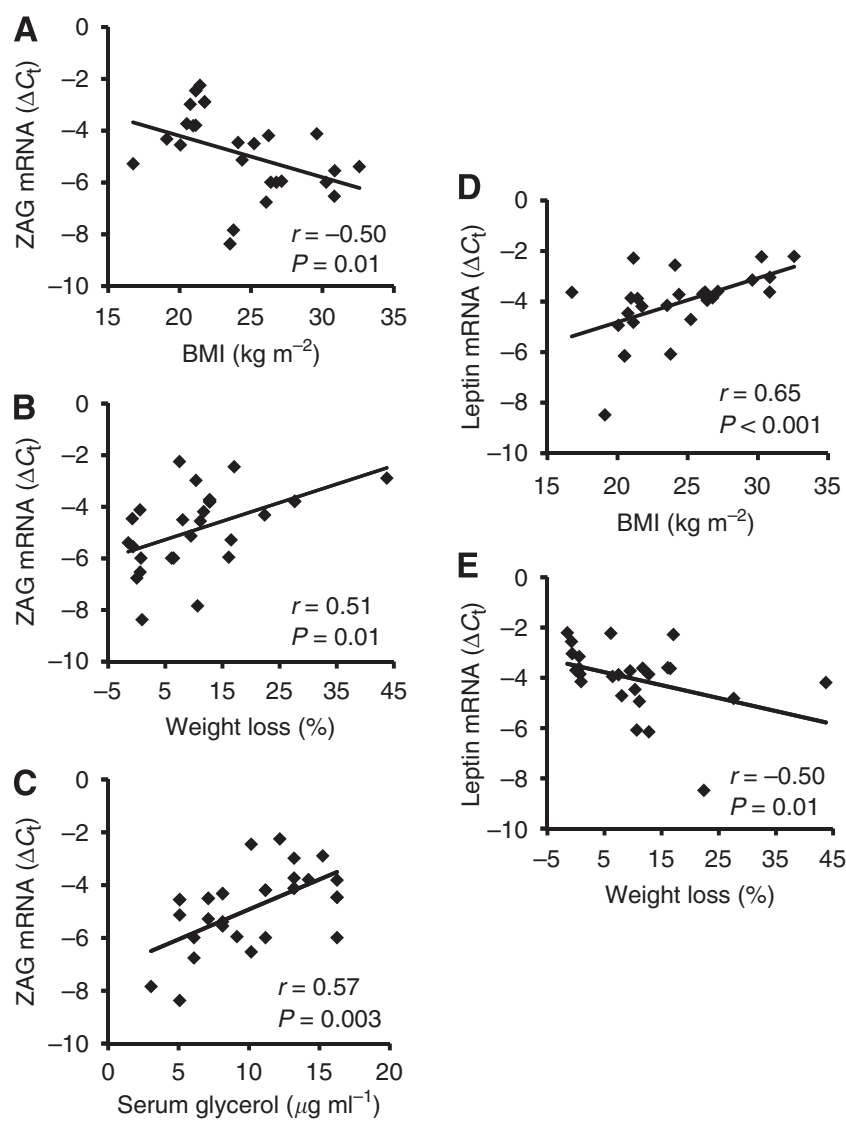

Figure 3 Correlation between ZAG mRNA levels in adipose tissue and $\mathrm{BMI}(\mathbf{A})$, weight loss (B) and serum glycerol $(\mathbf{C}) ; n=25$. Correlation between leptin mRNA levels in adipose tissue and BMI (D) and weight loss $(\mathbf{E}) ; n=25$. mRNA levels are presented as $\Delta C_{\mathrm{t}}$ relative to $\beta$-actin.

$P=0.045)$ and positive correlation with weight loss $(r=0.41$, $P=0.04)$.

Contrary to the results of ZAG, leptin mRNA level showed a positive correlation with BMI $(r=0.65, P<0.001)$ (Figure 3D), but were negatively correlated with weight loss $(r=-0.50, P=0.01)$ (Figure 3E).

\section{ZAG protein secretion from SAT is elevated in cachectic cancer patients}

As there is enhanced ZAG expression in SAT in cancer cachexia, we investigated whether there is an increase in ZAG protein release from the tissue. Zinc- $\alpha 2$-glycoprotein was secreted by the SAT explants at levels of about $10-210 \mathrm{ng}$ per g lipid per $2 \mathrm{~h}$. In line with the results of ZAG expression, a $50 \%$ increase in ZAG protein secretion by adipose tissue was found in cachectic cancer patients when compared with weight-stable cancer patients $(P=0.024)$ (Figure 4A). Furthermore, there was a positive correlation between ZAG protein secretion and weight loss in cancer patients $(r=0.50$, $P=0.003$ ) (Figure 4B).

\section{Treatment with ZAG stimulates glycerol release by human adipocytes}

In light of the upregulation of ZAG expression and secretion by adipose tissue in cancer cachexia, we investigated whether ZAG has a local effect through lipid mobilisation in human adipose tissue. Differentiated human adipocytes (SGBS) were treated
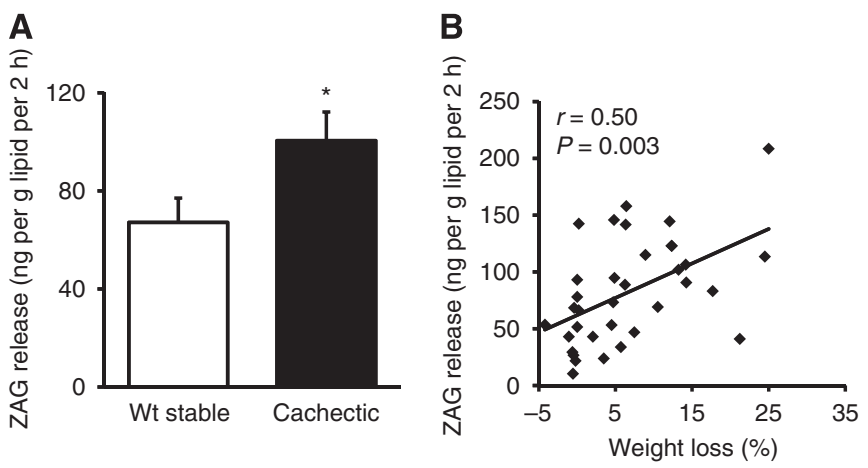

Figure 4 Zinc- $\alpha 2$-glycoprotein protein secretion by adipose tissue explants of cancer patients. (A) ZAG release was measured as the protein concentration in the medium of subcutaneous adipose tissue explants of weight-stable $(n=19)$ and cachectic $(n=15)$ cancer patients, expressed as means \pm s.e.m. (B) Correlation between ZAG secretion levels and weight loss; $n=44$. ${ }^{*} P<0.05$ compared with weight-stable patients.

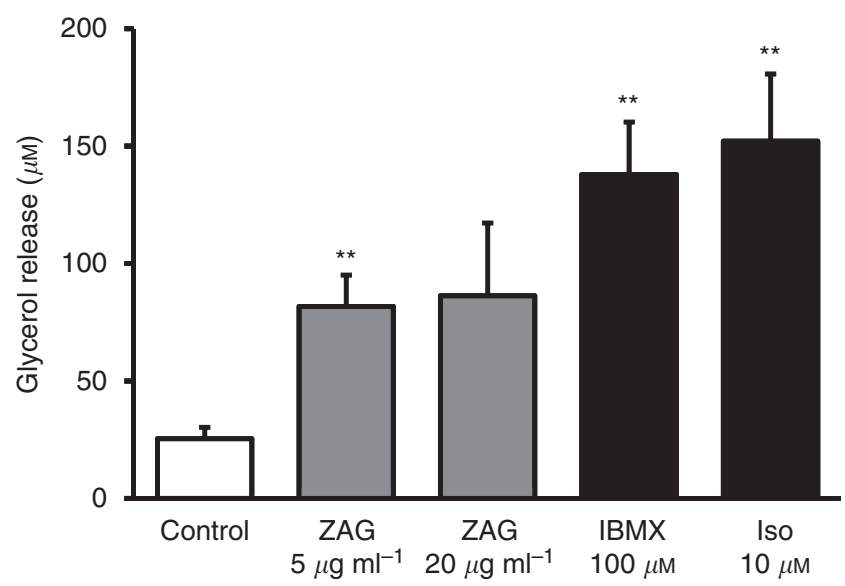

Figure 5 Effects of ZAG on glycerol release by human adipocytes. Differentiated SGBS adipocytes were incubated with recombinant ZAG (5 or $\left.20 \mu \mathrm{g} \mathrm{m}^{-1}\right)$, or isoproterenol $(10 \mu \mathrm{M})$ or IBMX $(100 \mu \mathrm{M})$ for $18 \mathrm{~h}$. Control cells received no addition. Glycerol concentrations in the culture medium were determined. Data are means \pm s.e.m., $n=4$ per group. ** $P<0.0$ l compared with controls.

with recombinant ZAG and the effect on lipolysis was examined. As shown in Figure 5, glycerol release by SGBS adipocytes was induced with a $>3$-fold increase at both the lower $\left(5 \mu \mathrm{g} \mathrm{ml}^{-1}\right)$ and higher $\left(20 \mu \mathrm{g} \mathrm{ml}^{-1}\right)$ doses of ZAG treatment, and the increase was statistically significant at the dose of $5 \mu \mathrm{g} \mathrm{ml}^{-1}(P<0.01)$. As positive controls, treatment with isoproterenol and IBMX led to a six- and five-fold increase in glycerol release, respectively (both $P<0.01$ ) (Figure 5).

\section{DISCUSSION}

This study shows profound changes in SAT morphology in patients with cancer cachexia. Adipose tissue atrophy is characterised by a reduction in adipocyte cell size, and this is accompanied by a significant increase in tissue matrix fibrosis. Similar alterations in adipose tissue structure have been observed in our previous study in cancer-bearing mice (Bing et al, 2006). In agreement with these changes in adipose tissue morphology, 
a decrease in fat cell volume without change in total fat cell number has been recently reported in cachectic patients with gastrointestinal cancer (Agustsson et al, 2007; Ryden et al, 2008). These results provide evidence that adipose tissue remodelling with reduced lipid storage occurs in human cancer cachexia.

Until now, there has been no information available on ZAG production in cancer cachexia in human subjects. The results of this study show that the expression levels of ZAG transcripts and protein in SAT were upregulated in cachectic cancer patients compared with weight-stable cancer patients. The enhanced adipose tissue ZAG expression in cancer cachexia suggests that ZAG could be a local catabolic mediator within the tissue. Further analyses show that ZAG expression in SAT was linked to adiposity and weight loss in cancer patients. We show that ZAG mRNA levels exhibited an inverse relationship with BMI, but a positive correlation with weight loss. In parallel, ZAG protein content in adipose tissue correlated negatively with BMI, but positively with weight loss. Similarly, a negative association between adipose tissue ZAG expression and BMI has been reported in studies of obese human subjects (Selva et al, 2009; Mracek et al, 2010a). These observations indicate a contributory role for ZAG in the modulation of body adiposity (Bing et al, 2010). In this study, however, no significant differences in serum ZAG levels were found between cachectic and weight-stable cancer patients. Other data on circulating ZAG levels in relation to human obesity are inconsistent, being reported as either decreased (CeperueloMallafre et al, 2009; Selva et al, 2009) or increased (Yeung et al, 2009). Circulating levels of ZAG could be influenced by its production in other tissues such as the liver, a major site for ZAG production (Tada et al, 1991). Although ZAG mRNA levels were lowered in $o b / o b$ mice (Mracek et al, 2010b) and obese patients (Selva et al, 2009), the extent of ZAG production by the liver in human cancer cachexia is not known and further studies are warranted. In addition, ZAG is known to be overexpressed by malignant tumours and this may over-ride the contribution of ZAG produced by adipose tissue to the circulating pool. Therefore, it is likely that adipose tissue-derived ZAG is more important locally through an autocrine/paracrine action.

In marked contrast to the results of ZAG, SAT leptin mRNA, which increases with fat mass accretion, is decreased in cachectic cancer patients. Furthermore, circulating leptin levels are also reduced in these patients. Leptin as a key adipokine is known to be an indicator of body adiposity (Kettaneh et al, 2007). The downregulation of leptin production in cachectic cancer patients is in agreement with a fall of adiposity in cancer cachexia.

Another key finding of this study is the demonstration that human adipose tissue secretes ZAG protein, and more importantly, the levels of ZAG secretion are higher in cachectic than in weightstable cancer patients. Local secretion of ZAG from adipose tissue in cachexia has not been described previously. This study is the first to show upregulated production of the adipokine, suggesting that it plays a key autocrine/paracrine role in the cachexiaassociated tissue atrophy. Importantly, further analyses reveal a positive relationship between ZAG protein release and weight loss in cancer patients. The elevation in ZAG production with increased severity of cachexia further supports a role for ZAG in catabolising body fat in human beings.

Although the molecular mechanisms of fat loss in cachexia remain to be established, increased lipolysis is considered to be a key factor. It has been shown that whole-body lipolysis, measured by the rate of appearance of glycerol, is higher in patients with cancer who are losing weight than in healthy subjects (Zuijdgeestvan Leeuwen et al, 2000). A recent study has shown that lipolytic activity (fasting plasma glycerol or fatty acids) is higher in cancer cachexia patients than in weight-stable controls (Agustsson et al, 2007). Furthermore, increased expression of hormone-sensitive lipase, a rate-limiting enzyme of the lipolytic pathway, has been reported in adipose tissue of patients with cancer cachexia (Thompson et al, 1993; Agustsson et al, 2007). In vitro, using mature adipocytes isolated from SAT, the lipolytic effects of catecholamines and natriuretic peptide were increased by $>2$-fold in cancer patients with cachexia compared with weight-stable cancer patients, although basal lipolysis was unaffected (Agustsson et al, 2007). In this study, we show a positive correlation between ZAG expression in adipose tissue and fasting serum glycerol levels, suggesting an involvement of ZAG in lipolytic activity.

The proposed role for ZAG in lipid mobilisation has primarily been based on studies in rodents and murine adipocytes (Hirai et al, 1998). Recent work has shown that ZAG-deficient mice are susceptible to weight gain when fed a high-fat diet, which appears to be the result of a decreased lipolytic response to adrenergic stimuli in white adipocytes, although basal lipolysis is not affected (Rolli et al, 2007). In ZAG-overexpressing transgenic mice, which exhibit decreased body weight and epididymal fat, mRNA levels of HSL in adipose tissue are elevated and the tissue is sensitised to the action of catecholamines (Gong et al, 2009). However, it is unclear whether this is the case in human beings with increased ZAG. We have shown that ZAG production (both expression and release) by SAT is increased in cachectic cancer patients, supporting a role for ZAG in human beings. Considering its action as a LMF in rodents, it is essential to examine further if ZAG acts as a catabolic mediator through its lipolytic effect in human adipose tissue. This study reveals that recombinant ZAG, at physiologically relevant concentrations, increases glycerol release from differentiated human adipocytes. Our finding suggests that ZAG could stimulate lipolysis in human adipose tissue, and therefore contribute to increased lipid mobilisation in human cancer cachexia. This result also provides the potential for novel therapeutic strategies against ZAG. The crystal structure of ZAG has been shown to have a high degree of similarity to the major histocompatibility complex class I molecules (Sanchez et al, 1999). As the hydrophobic groove formed by the $\alpha 1-\alpha 2$ domain of ZAG molecule may be important in lipid metabolism (McDermott et al, 2006; Hassan et al, 2008), further studies are warranted to assess whether blocking of this binding site and/or local ZAG production can be used for preventing the loss of adipose tissue in malignancy. On the other hand, ZAG might be employed for the treatment of visceral obesity as it stimulates lipolysis via $\beta_{3}$-adrenoceptors (Russell et al, 2004) and $\beta_{3}$-adrenoceptor sensitivity is enhanced in response to noradrenaline in visceral fat of obese subjects (Lönnqvist et al, 1995).

In conclusion, this study shows that in human subjects, ZAG expression and its protein secretion by SAT are enhanced in cancer cachexia irrespective of tumour stage. This upregulation of adipose tissue-derived ZAG is associated with the severity of cachexia. However, circulating ZAG levels do not differ between cachectic and weight-stable cancer patients. Finally, recombinant ZAG stimulates glycerol release from human adipocytes. Overall, our results suggest that adipokine ZAG plays a key role in the pathogenesis of cancer cachexia in human beings, at least in part, through its lipid mobilising action in adipose tissue.

\section{ACKNOWLEDGEMENTS}

We thank Professor Martin Wabitsch (University of Ulm) for the gift of SGBS adipocytes. We also thank Mrs Evelyn Beckett and Dr Qi Ding for expert technical assistance. All authors have participated in the study design, data analyses, drafting and revising the manuscript, and have approved the manuscript. This work was supported by the UK Biotechnology and Biological Sciences Research Council (BBE015379), the UK Medical Research Council (87972), Cancer Research UK (C1128/A7309), the Swedish Cancer Society and the Swedish Research Council. 


\section{REFERENCES}

Agustsson T, Ryden M, Hoffstedt J, van Harmelen V, Dicker A, Laurencikiene J, Isaksson B, Permert J, Arner P (2007) Mechanism of increased lipolysis in cancer cachexia. Cancer Res 67: 5531-5537

Albertus DL, Seder CW, Chen G, Wang X, Hartojo W, Lin L, Silvers A, Thomas DG, Giordano TJ, Chang AC, Orringer MB, Bigbee WL, Chinnaiyan AM, Beer DG (2008) AZGP1 autoantibody predicts survival and histone deacetylase inhibitors increase expression in lung adenocarcinoma. J Thorac Oncol 3: 1236-1244

Argiles JM, Busquets S, Felipe A, Lopez-Soriano FJ (2006) Muscle wasting in cancer and ageing: cachexia versus sarcopenia. Adv Gerontol 18: $39-54$

Bao Y, Bing C, Hunter L, Jenkins JR, Wabitsch M, Trayhurn P (2005) Zinc-alpha2-glycoprotein, a lipid mobilizing factor, is expressed and secreted by human (SGBS) adipocytes. FEBS Lett 579: $41-47$

Bing C, Bao Y, Jenkins J, Sanders P, Manieri M, Cinti S, Tisdale MJ, Trayhurn P (2004) Zinc-alpha2-glycoprotein, a lipid mobilizing factor, is expressed in adipocytes and is up-regulated in mice with cancer cachexia. Proc Natl Acad Sci USA 101: 2500-2505

Bing C, Mracek T, Gao D, Trayhurn P (2010) Zinc-alpha2-glycoprotein: an adipokine modulator of body fat mass? Int J Obes (Lond) 34: $1559-1565$

Bing C, Russell S, Becket E, Pope M, Tisdale MJ, Trayhurn P, Jenkins JR (2006) Adipose atrophy in cancer cachexia: morphologic and molecular analysis of adipose tissue in tumour-bearing mice. $\mathrm{Br} J$ Cancer 95: $1028-1037$

Bing C, Russell ST, Beckett EE, Collins P, Taylor S, Barraclough R, Tisdale MJ, Williams G (2002) Expression of uncoupling proteins-1, -2 and -3 mRNA is induced by an adenocarcinoma-derived lipid-mobilizing factor. Br J Cancer 86: 612-618

Bing C, Trayhurn P (2009) New insights into adipose tissue atrophy in cancer cachexia. Proc Nutr Soc 68: 385-392

Burgi W, Schmid K (1961) Preparation and properties of Zn-alpha 2-glycoprotein of normal human plasma. J Biol Chem 236: $1066-1074$

Ceperuelo-Mallafre V, Naf S, Escote X, Caubet E, Gomez JM, Miranda M, Chacon MR, Gonzalez-Clemente JM, Gallart L, Gutierrez C, Vendrell J (2009) Circulating and adipose tissue gene expression of zinc-alpha2glycoprotein in obesity: its relationship with adipokine and lipolytic gene markers in subcutaneous and visceral fat. J Clin Endocrinol Metab 94: $5062-5069$

Dewys WD, Begg C, Lavin PT, Band PR, Bennett JM, Bertino JR, Cohen MH, Douglass Jr HO, Engstrom PF, Ezdinli EZ, Horton J, Johnson GJ, Moertel CG, Oken MM, Perlia C, Rosenbaum C, Silverstein MN, Skeel RT, Sponzo RW, Tormey DC (1980) Prognostic effect of weight loss prior to chemotherapy in cancer patients. Eastern Cooperative Oncology Group. Am J Med 69: $491-497$

Diez-Itza I, Sanchez LM, Allende MT, Vizoso F, Ruibal A, Lopez-Otin C (1993) Zn-alpha 2-glycoprotein levels in breast cancer cytosols and correlation with clinical, histological and biochemical parameters. Eur J Cancer 29A: 1256-1260

Fearon KC, Voss AC, Hustead DS (2006) Definition of cancer cachexia: effect of weight loss, reduced food intake, and systemic inflammation on functional status and prognosis. Am J Clin Nutr 83: $1345-1350$

Fouladiun M, Korner U, Bosaeus I, Daneryd P, Hyltander A, Lundholm KG (2005) Body composition and time course changes in regional distribution of fat and lean tissue in unselected cancer patients on palliative care - correlations with food intake, metabolism, exercise capacity, and hormones. Cancer 103: 2189-2198

Gong FY, Zhang SJ, Deng JY, Zhu HJ, Pan H, Li NS, Shi YF (2009) Zinc-alpha2-glycoprotein is involved in regulation of body weight through inhibition of lipogenic enzymes in adipose tissue. Int $J$ Obes (Lond) 33: $1023-1030$

Hale LP (2002) Zinc alpha-2-glycoprotein regulates melanin production by normal and malignant melanocytes. J Invest Dermatol 119: $464-470$

Hale LP, Price DT, Sanchez LM, Demark-Wahnefried W, Madden JF (2001) Zinc alpha-2-glycoprotein is expressed by malignant prostatic epithelium and may serve as a potential serum marker for prostate cancer. Clin Cancer Res 7: 846-853

Hassan MI, Waheed A, Yadav S, Singh TP, Ahmad F (2008) Zinc alpha(2)glycoprotein: a multidisciplinary protein. Mol Cancer Res 6: $892-906$

He N, Brysk H, Tyring SK, Ohkubo I, Brysk MM (2001) Zinc-alpha(2)glycoprotein hinders cell proliferation and reduces cdc2 expression. J Cell Biochem 81: $162-169$
Hirai K, Hussey HJ, Barber MD, Price SA, Tisdale MJ (1998) Biological evaluation of a lipid-mobilizing factor isolated from the urine of cancer patients. Cancer Res 58: 2359-2365

Kettaneh A, Heude B, Romon M, Oppert JM, Borys JM, Balkau B, Ducimetiere P, Charles MA (2007) High plasma leptin predicts an increase in subcutaneous adiposity in children and adults. Eur J Clin Nutr 61: 719-726

Lieffers JR, Mourtzakis M, Hall KD, McCargar LJ, Prado CM, Baracos VE (2009) A viscerally driven cachexia syndrome in patients with advanced colorectal cancer: contributions of organ and tumor mass to whole-body energy demands. Am J Clin Nutr 89: 1173-1179

Lönnqvist F, Thöme A, Nilsell K, Hoffstedt J, Arner P (1995) A pathogenic role of visceral fat beta 3 -adrenoceptors in obesity. J Clin Invest 95: $1109-1116$

McDermott LC, Freel JA, West AP, Bjorkman PJ, Kennedy MW (2006) $\mathrm{Zn}$-alpha2-glycoprotein, an MHC class I-related glycoprotein regulator of adipose tissue: modification or abrogation of ligand binding by site-directed mutagenesis. Biochemistry 45: 2035-2041

Moses AG, Dowidar N, Holloway B, Waddell I, Fearon KC, Ross JA (2001) Leptin and its relation to weight loss, ob gene expression and the acute-phase response in surgical patients. Br J Surg 88: $588-593$

Mracek T, Ding Q, Tzanavari T, Kos K, Pinkney J, Wilding J, Trayhurn P, Bing C (2010a) The adipokine zinc-alpha2-glycoprotein is downregulated with fat mass expansion in obesity. Clin Endocrinol (Oxf) 72: 334-341

Mracek T, Gao D, Tzanavari T, Bao Y, Xiao X, Stocker C, Trayhurn P, Bing C (2010b) Downregulation of zinc-\{alpha\}2-glycoprotein in adipose tissue and liver of obese ob/ob mice and by tumour necrosis factor-\{alpha\} in adipocytes. J Endocrinol 204: 165-172

Rolli V, Radosavljevic M, Astier V, Macquin C, Castan-Laurell I, Visentin V, Guigne C, Carpene C, Valet P, Gilfillan S, Bahram S (2007) Lipolysis is altered in MHC class I zinc-alpha(2)-glycoprotein deficient mice. FEBS Lett 581: 394-400

Russell ST, Tisdale MJ (2010) Antidiabetic properties of zinc-\{alpha\}2glycoprotein in ob/ob mice. Endocrinology 151: $948-957$

Russell ST, Zimmerman TP, Domin BA, Tisdale MJ (2004) Induction of lipolysis in vitro and loss of body fat in vivo by zinc-alpha2-glycoprotein. Biochim Biophys Acta 1636: 59-68

Ryden M, Agustsson T, Laurencikiene J, Britton T, Sjolin E, Isaksson B, Permert J, Arner P (2008) Lipolysis - not inflammation, cell death, or lipogenesis - is involved in adipose tissue loss in cancer cachexia. Cancer 113: 1695 - 1704

Sanchez LM, Chirino AJ, Bjorkman P (1999) Crystal structure of human ZAG, a fat-depleting factor related to MHC molecules. Science 283: $1914-1919$

Schmitt R, Marlier A, Cantley LG (2008) Zag expression during aging suppresses proliferation after kidney injury. J Am Soc Nephrol 19: 2375-2383

Selva DM, Lecube A, Hernandez C, Baena JA, Fort JM, Simo R (2009) Lower zinc-alpha2-glycoprotein production by adipose tissue and liver in obese patients unrelated to insulin resistance. J Clin Endocrinol Metab 94: $4499-4507$

Sobin LH, Wittekind C (2002) TNM Classification of Malignant Tumours, 6th edn. John Wiley \& Sons: Hoboken, NJ

Tada T, Ohkubo I, Niwa M, Sasaki M, Tateyama H, Eimoto T (1991) Immunohistochemical localization of $\mathrm{Zn}$-alpha 2-glycoprotein in normal human tissues. J Histochem Cytochem 39: 1221-1226

Thompson MP, Cooper ST, Parry BR, Tuckey JA (1993) Increased expression of the mRNA for hormone-sensitive lipase in adipose tissue of cancer patients. Biochim Biophys Acta 1180: 236-242

Tisdale MJ (2005) Molecular pathways leading to cancer cachexia. Physiology (Bethesda) 20: 340-348

Todorov PT, McDevitt TM, Meyer DJ, Ueyama H, Ohkubo I, Tisdale MJ (1998) Purification and characterization of a tumor lipid-mobilizing factor. Cancer Res 58: $2353-2358$

Trayhurn P, Bing C (2006) Appetite and energy balance signals from adipocytes. Philos Trans R Soc Lond Ser B 361: 1237-1249

Yeung DC, Lam KS, Wang Y, Tso AW, Xu A (2009) Serum zinc-alpha2glycoprotein correlates with adiposity, triglycerides, and the key components of the metabolic syndrome in Chinese subjects. J Clin Endocrinol Metab 94: 2531 - 2536

Zuijdgeest-van Leeuwen SD, van den Berg JW, Wattimena JL, van der Gaast A, Swart GR, Wilson JH, Dagnelie PC (2000) Lipolysis and lipid oxidation in weight-losing cancer patients and healthy subjects. Metabolism 49: $931-936$ 